\title{
POPULATION STATUS AND ECOLOGY OF PLATANTHERA CHLORANTHA (ORCHIDACEAE) IN THE GREATER CAUCASUS (AZERBAIJAN)
}

\author{
Nigar Mursal, Naiba P. Mehdiyeva, Aida G. Ibrahimova \\ Institute of Botany of Azerbaijan National Academy of Science, Azerbaijan \\ e-mail: nigarbiology1292@mail.ru
}

Received: 28.03.2020. Revised: 29.07.2020. Accepted: 11.08.2020.

\begin{abstract}
Long-term conservation schemes usually concern the rarest species, extremely threatened. Investigating Red Data Book species is inescapable for determining their threatened category and optimal measures for the protection. Orchidaceae is the most attractive plant family among all plant families of the world. Due to decorative, medicinal, food features of orchid species, their populations are declining. Seventeen threatened orchid species are included in the Red Data Book of the Republic of Azerbaijan. One of them is Platanthera chlorantha. The ontogenetic and morphometric structure of $P$. chlorantha populations was previously studied fragmentarily. However, the vitality structure, and the environment influence on its populations have not been studied in Azerbaijan yet. The aim of the present paper was to study its ontogenetic, demographic and vitality structure in order to elucidate the influence of climatic and edaphic factors on morphometric variability. The field investigations were carried out in 2016-2019 in Khizi, Siyazan, Guba, Gusar, Shamakhi, Ismayilli and Gakh districts of the Greater Caucasus using both population-based and geobotanical methods. A morphometric analysis was performed on 30 randomly selected generative individuals in the nine studied populations. Relationships between distribution of some orchid species, their environmental preferences and environmental variables were analysed using canonical correspondence analysis (CCA). The phenology of $P$. chlorantha has been studied. We revealed that a temperate, warm, humid climate and mountain-brownish soil type are most favourable for P. chlorantha.
\end{abstract}

Key words: endangered species, morphological variability, ontogenetic structure, orchid, ordination, phenology, species abundance, vitality structure

\section{Introduction}

Biodiversity is declining sharply, with over a million species currently threatened with extinction (Johnson et al., 2017). Species conservation is significantly important around the world (Ceballos et al., 2015; IPBES, 2019). Habitat loss and biological invasions are also driving factors for many plant extinctions (Le Roux et al., 2019). Biological invasions are widely considered as a main threat to global biodiversity. Invasive species of all taxonomic groups increase the threat to native biodiversity by a range of impacts (Helm et al., 2006; Brook et al., 2008; Downey \& Richardson, 2016). Due to human activities thousands of plants are at risk of extinction including many orchid species (Wraith \& Pickering, 2019). These threats lead to species extinction, which is now several orders higher than in the past (Pimm \& Raven, 2000; Evans et al., 2011). Such factors as a small population size, limited distribution and species-specific relationships with pollinators and mycorrhizal fungi could cause to the extinction of many orchids (Seaton et al., 2013).

Orchids are the most diverse group of flowering plants with over 26500 species occurring in a wide range of bioregions (Cribb et al., 2003; Li et al., 2018; Fay, 2018). In the Azerbaijan flora, the family Orchidaceae Juss. is represented by 48 species belonging to 19 genera (Rzazade, 1952). Of them, Platanthera Rich. includes 70 species in the world flora. Among these species, only Platanthera bifolia (L.) Rich. and
P. chlorantha (Cust.) Reichenb. are known from the Caucasus and Azerbaijan. Platanthera chlorantha has a European-Asian species' range and a smaller ecological amplitude than P. bifolia. It prefers well-aerated soils. In Azerbaijan, the range of $P$. chlorantha covers the southern part of the Lesser Caucasus, Gobustan, the Lenkaran mountainous region and the Greater Caucasus. It inhabits forests and shrublands from lowlands to the middle mountain zone and grows mainly in broadleaved forests, meadows, forest edges and roadsides (Rzazade, 1952; Vakhrameeva et al., 2008). Platanthera chlorantha is included in the Red Data Book of the Republic of Azerbaijan (2013) with status VU D2.

Platanthera chlorantha (Greater butterfly orchid) is a herbaceous perennial plant of $30-60 \mathrm{~cm}$ in height. The stem is erect, simple, having two large oblongovate leaves at the base. There are 1-3 small lanceolate leaflets in the upper part of the stem. The flowers are in a cylindrical spike, greenish-white, almost odourless. The lip is undivided, with a long spur, pin-shaped thickened at the end. The underground part is represented by a short rhizome with subordinate roots and two root tubers of oblong-ovate shape with awl-shaped ends. It blooms in May - June (Alizade et al., 2019).

The paper was aimed 1) to study the ontogenetic and vitality structure of populations (Pop); 2) to reveal the variability of morphological parameters of $P$. chlorantha individuals; 3) to investigate the impact of climatic and edaphic factors on morphological parameters. 


\section{Material and Methods}

The field investigations were conducted from April to October in 2016-2019 in Khizi, Siyazan, Guba, Gusar, Shamakhi, Ismayilli and Gakh districts of the Greater Caucasus using population-based and geobotanical methods (Fig. 1).

\section{Description of the studied habitats}

Pop1 was studied in hornbeam-oak (Carpinuseto-Quercusetum) forest in the village Ispik of Quba district ( $861 \mathrm{~m}$ a.s.1.). The projective cover of herbs is $80 \%$. In the plant community $P$. chlorantha coexists with trees as Fagus orientalis Lipsky, Carpinus betulus L., Quercus petraea subsp. polycarpa (Schur) Soó, Acer campestre L.; shrubs as Crataegus rhipidophylla Gand., Rubus idaeus L.; herbs as Arum elongatum Steven, Leontodon hispidus L., Onobrychis bobrovii A.Grossh., Primula woronowii Losinsk., Orchis purpurea Huds., Ophrys apifera Huds., Epipactis palustris (L.) Crantz, Corydalis angustifolia (M.Bieb.) DC.

Pop2 was investigated in beech-oak (FagusetoQuercusetum) forest in the village Nugedi of Quba district (588 $\mathrm{m}$ a.s.1.). The projective cover of herbs is $75 \%$. In the plant community $P$. chlorantha coexists with trees as Fagus orientalis, Carpinus betulus, Corylus colurna L., Acer cappadocicum Gled.; shrubs as Crataegus rhipidophylla, Rubus aetnicus Weston, Rosa pulverulenta M.Bieb.; herbs as Arum elongatum, Corydalis marschalliana (Willd.) Pers., Primula woronowii, Viola sieheana W. Becker, Orchis purpurea, Cephalanthera longifolia (L.) Fritsch, Lonicera xylosteum L., Geranium sylvaticum L., Leontodan hispidus. The plant community Primula woronowii + Corydalis marschalliana + Viola sieheana forms a microassosiation with $P$. chlorantha in the herbaceous layer.

Pop3 was found in the village Piral of Qusar district (788 $\mathrm{m}$ a.s.1.). The projected cover of herbs is $80 \%$. In the plant community P. chlorantha co-exists with trees as: Carpinus betulus, Fagus orientalis, Fraxinus excelsior L., Acer cappadocicum, Corylus colurna; shrubs as: Crataegus curvisepala Lindm., Rubus caucasicus Focke; herbs as: Lonicera etrusca Santi, Corydalis angustifolia, Cephalanthera rubra (L.) Rich., C. longifolia, Trifolium pratense L., Primula woronowii, Poa supina Schrad., Galium verum L., Ajuga genevensis L., Ranunculus cicutarius Schltdl., Rumex crispus L., Rhamnus pallasii Fisch. \& C.A.Mey., Stachys byzantina K.Koch., Bellis perennis L., Fragaria viridis Weston, Plantago lanceolata L., Galanthus alpinus Sosn.



Fig. 1. The map of Platanthera chlorantha locations studied in the Greater Caucasus. The populations located in different districts are indicated with different signs.

Pop4 was studied in oak-hornbeam (Quercuseto-Carpinusetum) in the village Qizilqazma of Khizi district (1043 $\mathrm{m}$ a.s.1.). The projected cover of herbs is $70 \%$. Trees co-existing with $P$. chlorantha are Carpinus betulus, Acer campestre, Fagus orientalis, Quercus pubescens subsp. crispata (Steven) Greuter \& Burdet; shrubs: Rubus aetnicus, Rosa corymbifera Borkh., Crataegus curvisepala; herbs: Orchis purpurea, Primula woronowii, Cephalanthera rubra, Phelipaea coccinea (M. Bieb.) Poir., Ophrys sphegodes subsp. mammosa (Desf.) Soó ex E.Nelson, Arum elongatum.

Pop5 was revealed in the hornbeam-maple (Carpinuseto-Aceretum) forest in Qalaalti district of the village Siyazan (709 m a.s.1.) located to near oil tanks. The project covers of herbs is $90 \%$. In the plant community, the orchid co-exists with trees Fagus orientalis, Crataegus germanica (L.) Kuntze, Quercus machranthera Fisch. et C.A.Mey. ex Hohen., Carpinus betulus, Acer campestre, Malus orientalis Uglitzk.; shrubs Crataegus curvisepala, Rosa canina L.; herbs Primula woronowii, Viola arvensis Murray, Scilla siberica Andrews, Allium paradoxum (M.Bieb.) G.Don, Dactylorhiza romana subsp. georgica (Klinge) Soó ex Renz \& Taubenheim, Arum elongatum, Orchis purpurea, Ranunculus polyanthemos L., Himanthoglossum formossum (Stev.) K.Koch, Lonicera etrusca.

Pop6 was investigated in the dark forest in the village Erchiman of Shamakhi district (1299 m a.s.1.). The projected cover of herbs is $90 \%$. In the plant community $P$. chlorantha co-exists with trees 
as Fagus orientalis, Taccus baccata L., Acer campestre, Quercus petraea subsp. polycarpa, Fraxinus excelsior; shrubs as Rubus aetnicus; herbs as Primula woronowii, Silene italica (L.) Pers., Hordeum murinum subsp. leporinum (Link) Arcang., Galium rubioides L., Poa nemoralis L., Laser trilobum (L.) Borkh., Alliaria petiolata (Bieb.) Cavara \& Grande, Neottia nidus-avis (L.) Rich., Orchis purpurea, Cephalanthera rubra, C. grandiflora, Corydalis marschalliana, Stachys lanata Jacq., Neottia ovata (L.) Bluff \& Fingerh.

Pop7 was studied in the forest in the Ismayilli district ( $830 \mathrm{~m}$ a.s.1.). The projective cover of herbs is $65 \%$. Platanthera chlorantha co-exists with trees as Fagus orientalis, Acer cappadocicum, A. campestre, A. platanoides L., Carpinus betulus, Cornus mas L., Quercus petraea subsp. polycarpa, invasive Robinia pseudacacia L.; shrubs as Crataegus curvisepala; herbs as Corydalis marschalliana, Primula woronowii, Cephalanthera rubra, Thalictrum minus L., Alliaria petiolata, Vicia narbonensis L., Limodorum abortivum (L.) Sw., Lonicera etrusca.

Pop8 was revealed in the forest along the road to the waterfall in the village Lakit of Gakh district ( $830 \mathrm{~m}$ a.s.1.). The project cover of herbs is $80 \%$. In the plant community, $P$. chlorantha co-exists with trees as Pterocarya fraxinifolia (Poir.) Spach, Acer campestre, Carpinus betulus, Cornus mas, Diospyros lotus L., Acer velutinum Boiss.; shrubs as Crataegus curvisepala; herbs as Geranium collinum Stephan ex Willd., Arum elongatum, Asplenium adiantumnigrum L., Asplenium incisum Thunb., Asplenium scolopendrium L., Polypodium vulgare L.

Pop9 was investigated in the forest at the mountain slopes bordering the Ilisu State Reserve in the village Gakhbash of Gakh district (810 $\mathrm{m}$ a.s.1.). The projected cover of herbs is $90 \%$. Platanthera chlorantha coexists with trees as Carpinus orientalis (dominant), Carpinus betulus, Quercus machranthera, Crataegus germanica; shrubs as Crataegus curvisepala; herbs as Orchis purpurea, Neottia ovata, Cephalanthera longifolia, C. caucasica, Fragaris vesca L., Primula woronowii, Ajuga genevensis L., Smyrnium perfoliatum L., Phedimus stolonifer (S.G.Gmel.) 't Hart, Arum elongatum, Dryopteris filix-mas (L.) Schott.

Climatic and edaphic factors of the study sites

Qusar district and Siyazan district where Pop3 and Pop5 were noted have a Mediterranean climate type. It is characterised by dry and very hot summers and mild winters. In the foothills area of Guba Nugedi district (Pop2), the climate is subtropical with mild winters and warm summers. In the high- altitude forests (Quba Ispik, Khizi, Shamakhi, Ismayilli, Qakh Lekit, Qakh Qakhbash) where Pop1, Pop4, Pop6, Pop7, Pop8 and Pop9 were detected respectively, the climate is temperate, warm and humid (Table 1) (Babaev et al., 2006).

The highest $\mathrm{pH}$ (7.2) values of the soils were found in Pop3 and Pop5, while the lowest $\mathrm{pH}$ (5.9) values and maximal values of the nitrogen content $(0.62 \%)$, the ratio $\mathrm{C} / \mathrm{N}$ (carbon/nitrogen ratio) (12) and humus content (12.7\%) were detected in Pop1, Pop4, Pop6, Pop7, Pop8 and Pop9. The lowest values of $\mathrm{C} / \mathrm{N}(6.8)$ and humus content (4.48\%) were noted in Pop2.

\section{Methods}

The description of plant communities was carried out according to Ipatov \& Kirikova (1998) and Mirkin (2001). The scientific names are given according to Plants of the World Online (http://www. plantsoftheworldonline.org/). The ontogenesis and demographic structure of populations have been studied according to Uranov (1975), Zaugolnova et al. (1988), Zhukova (1995), Ishkinina \& Ishmuratova (2007). Since $P$. chlorantha is a rare species, the study of its ontogenesis was carried out with a minimal number of individuals (10 individual per age class), photographs were taken of different ontogenetic classes. We revealed four periods (latent, pregenerative, generative and postgenerative) and eight age classes (juvenile (j), immature (im), virginile (mature vegetative) (v), young generative (g1), mature generative (g2), old generative (g3), subsenile (ss), senile (s).

To identify the main demographic parameters of populations, we studied the ontogenetic structure and the vitality structure. To study the abundance and the ontogenetic structure of $P$. chlorantha populations, we established 25-30 study plots $\left(1 \mathrm{~m}^{2}\right)$ arranged within 5-10 transects $\left(10 \mathrm{~m}^{2}\right)$ per each study site. To determine the age structure of each population at these locations, we measured the total number of individuals and the number of individuals of each age class. The population type was determined according to Zhivotovsky (2001) classification of normal populations «delta-omega» $(\Delta-\omega)$.

Morphometric analysis was carried out on the basis of 30 randomly selected generative individuals per population (Zlobin et al., 2013). A plant individual was considered as a counting unit. The morphological parameters of the aboveground parts of individuals were studied by counting length and width of the generative shoots, length and width of leaves, number of flowers and leaf veins. 
Table 1. Climatic and edaphic features of the study sites (Source: Babaev et al., 2006)

\begin{tabular}{|c|c|c|c|c|c|c|c|}
\hline & \multicolumn{3}{|c|}{ Climatic } & \multicolumn{4}{|c|}{ Edaphic } \\
\hline & Tem $\left({ }^{\circ} \mathrm{C}\right)$ & Prec (mm) & Evap (mm) & Humus (\%) & $\mathrm{N}(\%)$ & $\mathrm{C} / \mathrm{N}$ & $\mathrm{pH}$ \\
\hline Pop1 & $6.2-9.0$ & $570-950$ & $500-700$ & 12.7 & 0.62 & 12 & 5.9 \\
\hline Pop2 & $12.0-13.0$ & $110-488$ & $700-800$ & 4.48 & 0.38 & 6.8 & 7.2 \\
\hline Pop3 & $8.4-10.8$ & $450-600$ & $530-970$ & 7.41 & 0.52 & 8.2 & 7.2 \\
\hline Pop4 & $6.2-9.0$ & $570-950$ & $500-700$ & 12.7 & 0.62 & 12 & 5.9 \\
\hline Pop5 & $8.4-10.8$ & $450-600$ & $530-970$ & 7.41 & 0.52 & 8.2 & 7.2 \\
\hline Pop6 & $6.2-9.0$ & $570-950$ & $500-700$ & 12.7 & 0.62 & 12 & 5.9 \\
\hline Pop7 & $6.2-9.0$ & $570-950$ & $500-700$ & 12.7 & 0.62 & 12 & 5.9 \\
\hline Pop8 & $6.2-9.0$ & $570-950$ & $500-700$ & 12.7 & 0.62 & 12 & 5.9 \\
\hline Pop9 & $6.2-9.0$ & $570-950$ & $500-700$ & 12.7 & 0.62 & 12 & 5.9 \\
\hline
\end{tabular}

Note: Tem - temperature, Prec - Precipitation, Evap - evaporation, $\mathrm{N}$ - nitrogen, C/N - carbon/nitrogen ratio.

The study of the vitality structure of populations was carried out according to Zlobin (1989). To assess the degree of thriving or depression of population, the $\mathrm{I}_{\mathrm{Q}}$ index was used. To assess the vitality of individuals, we used the vitality index (IVC) (Ishbirdin et al., 2005).

Daily phenology (Beideman, 1960; Primack, $1985)$ of $P$. chlorantha individuals introduced in the Experiment Station of Central Botanical Garden of Azerbaijan National Academy of Science has been detected using such stages as appearance of the first leaf, the beginning of flowering, the flowering period and the flowering end.

An Experiment Station is located in Badamdar district of Baku city. The climate is mainly temperate hot and dry subtropical, with an average monthly temperature of $3.4^{\circ} \mathrm{C}$ in January and $25-26^{\circ} \mathrm{C}$ in July. The annual precipitation fluctuates between $150 \mathrm{~mm}$ and $300 \mathrm{~mm}$ (Mamedov et al., 2010).

\section{Data analysis}

Relationships between distribution of some orchid species, their environmental preferences and environmental variables were analysed using canonical correspondence analysis (CCA). CCA is based on an assumption that the species' response to environment gradient is unimodal. CCA relates directly to the response on the measured environmental variables (direct gradient analysis). It shows visually relationships between species, study sites, environmental variables on the same ordination plot (ter Braak, 1986). Ward's hierarchical clustering using Euclidian distance was carried out on the basis of the mean values of morphological parameters.

Statistical data processing was carried out for each parameter. The arithmetic mean value with standard error $(\mathrm{M} \pm \mathrm{m})$ and the standard deviation (SD) were determined. All statistical analyses were carried out in the programs PAST 3.15 (Hammer et al., 2001), and Microsoft Excel 2010. A distribution map of Platanthera chlorantha was created using ArcGIS 10.5.

\section{Results}

\section{Ontogenesis}

Fruiting begins in July. Seed ripening occurs in September. The size and shape of the fruit capsules are ellipsoidal, with 3-5 cm in length. Seeds are very small, light and dusty-shaped. The pregenerative period includes juvenile, immature and virginile age classes. The juvenile individual has one narrow-lanceolate leaf. The leaf base is elongated, and its upper part is pointed. The tuber has a thickened fusiform shape. An immature individual has lanceolate-elliptical leaf blades and round-elliptical tubers. The virginile individual has two elliptical or oblong-ovate leaves. The tuber becomes elongated and thickened. Its lower part is narrowed. The generative period includes young, mature and old generative age classes. The young and mature generative plants have two oblong-ovate leaves. The old generative plants have two (sometimes three) leaves. The subsenile plants represent the postgenerative period. They have two oblong-ovate leaves and (rarely) an inner leaf. The senile individuals have two leaves (Fig. 2, Table 2).

\section{Ontogenetic structure}

In the study area, the ontogenetic structure of $P$. chlorantha shows that almost all populations are normal. However, Pop3, Pop4, Pop5 and Pop8 are incomplete due to the absence of subse- 
nile individuals. We found the highest number of juvenile individuals in Pop3, immature individuals in Pop5, virginile individuals in Pop8, young generative individuals in Pop9, mature generative individuals in Pop4, old generative, subsenile and senile individuals in Pop1. In the nine studied populations, the highest number of pregenerative individuals was noted in Pop5 $(65.51 \%)$ while the lowest proportion was found in Pop1 (42.46\%). The highest proportion of generative individuals was observed in Pop7 and Pop9 (50.99\%), the lowest proportion in Pop5 (34.48\%). The maximal values of individuals in postgenerative age class were detected in Pop1 (8.21\%), while they were absent in Pop5 (0\%) (Fig. 3).
Spatial and demographic indicators of $P$. chlorantha populations are presented in Table 3. The highest average density and abundance of individuals of all ontogenetic states were noted in Pop6 and Pop7, and the lowest in Pop4. The highest density of pregenerative individuals was observed in Pop5, generative individuals in Pop6 and postgenerative individuals in Pop1. The recovery index showing how much of the generative proportion can regenerate undergrowth after dying, is higher in Pop9 and low in Pop7. The highest values of the replacement index are observed in Pop5, and aging is observed in Pop2. According to the indices $\Delta$ and $\omega$, only Pop 1 is transitional, and the remaining populations are assigned as young type.


Fig. 2. The age classes of Platanthera chlorantha. Designation: $\mathrm{j}$ - juvenile, im - immature, v - virginile, g1 - young generative, g2 - mature generative, g3 - old generative, ss - subsenile, $\mathrm{s}$ - senile.

Table 2. Morphological parameters of Platanthera chlorantha individuals of different age classes

\begin{tabular}{|c|c|c|c|c|}
\hline Age class & Leaf length $(\mathrm{cm})$ & Leaf width $(\mathrm{cm})$ & Number of veins & Number of subordinate roots \\
\hline $\mathrm{j}$ & $6.5 \pm 0.8$ & $1.1 \pm 0.1$ & $2.0 \pm 0.3$ & $2.0 \pm 0.3$ \\
\hline $\mathrm{im}$ & $10.3 \pm 1.3$ & $2.3 \pm 0.3$ & $7.2 \pm 1.1$ & $3.0 \pm 0.4$ \\
\hline $\mathrm{V}$ & $15.2 \pm 1.9$ & $2.8 \pm 0.4$ & $11.3 \pm 1.6$ & $5.0 \pm 0.6$ \\
\hline $\mathrm{g} 1$ & $13.5 \pm 1.7$ & $3.5 \pm 0.4$ & $20.0 \pm 2.8$ & $8.0 \pm 1.1$ \\
\hline $\mathrm{g} 2$ & $17.1 \pm 2.2$ & $3.2 \pm 0.4$ & $16.8 \pm 2.3$ & $9.2 \pm 1.2$ \\
\hline $\mathrm{g} 3$ & $12.4 \pm 1.6$ & $2.9 \pm 0.3$ & $12.4 \pm 1.7$ & $10.0 \pm 1.3$ \\
\hline $\mathrm{ss}$ & $11.6 \pm 1.5$ & $4.1 \pm 0.5$ & $11.4 \pm 1.6$ & $10.5 \pm 1.4$ \\
\hline $\mathrm{s}$ & $12.8 \pm 1.2$ & $5.2 \pm 0.6$ & $12.1 \pm 1.5$ & $12.2 \pm 2.1$ \\
\hline
\end{tabular}

Note: $\mathrm{j}$ - juvenile, im - immature, $\mathrm{v}$ - virginile, g1 - young generative, g2 - mature generative, g3 - old generative, ss - subsenile, $\mathrm{s}$ - senile. 


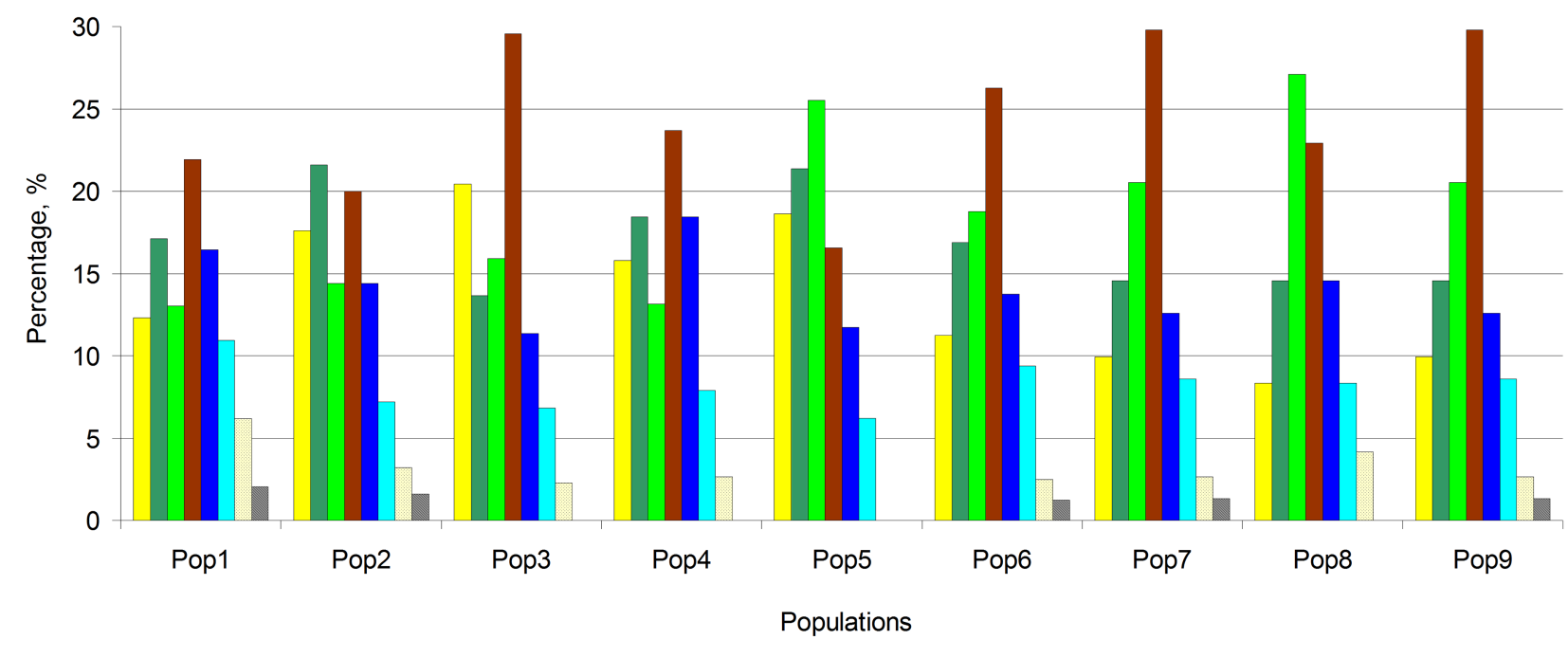

$\square \mathrm{j} \square \mathrm{im} \square \mathrm{v} \square \mathrm{g} 1 \square \mathrm{g} 2 \square \mathrm{g} 3 \square \mathrm{ss} \square \mathrm{s}$

Fig. 3. Ontogenetic spectrum of Platanthera chlorantha populations in the Greater Caucasus (Azerbaijan).

Table 3. Spatial and demographic parameters of Platanthera chlorantha populations in the Greater Caucasus (Azerbaijan)

\begin{tabular}{|c|c|c|c|c|c|c|c|c|c|c|}
\hline Pop & $\mathrm{n}$ & $\mathrm{X}_{a}$ & $\mathrm{X}_{\text {nre }}$ & $\mathrm{X}_{\mathrm{g}}$ & $\mathrm{X}_{\text {nost }}$ & $\mathrm{I}_{\mathrm{r}}$ & $\mathrm{I}_{a}$ & $\mathrm{I}_{\text {rep }}$ & $\Delta$ & $\omega$ \\
\hline 1 & 146 & 18.25 & 7.7 & 9 & 1.5 & 0.86 & 0.738 & 0.082 & 0.364 & 0.548 \\
\hline 2 & 125 & 15.625 & 8.375 & 6.5 & 0.75 & 1.288 & 1.155 & 0.048 & 0.303 & 0.487 \\
\hline 3 & 44 & 5.5 & 2.75 & 2.625 & 0.125 & 0.047 & 0.022 & 1 & 0.291 & 0.515 \\
\hline 4 & 38 & 4.75 & 2.25 & 2.375 & 0.125 & 0.947 & 0.026 & 0.9 & 0.310 & 0.543 \\
\hline 5 & 145 & 18.125 & 11.875 & 6.25 & 0 & 1.9 & 0 & 1.9 & 0.23 & 0.46 \\
\hline 6 & 160 & 20 & 9.375 & 9.875 & 0.75 & 0.949 & 0.037 & 0.882 & 0.307 & 0.548 \\
\hline 7 & 151 & 18.875 & 8.5 & 9.625 & 0.75 & 0.883 & 0.039 & 0.819 & 0.304 & 0.562 \\
\hline 8 & 64 & 8 & 7.875 & 4.375 & 0.5 & 1.09 & 0.04 & 1 & 0.296 & 0.555 \\
\hline 9 & 48 & 6 & 6 & 2.75 & 0.25 & 1.636 & 0 & 1.636 & 0.205 & 0.455 \\
\hline
\end{tabular}

Note: $\mathrm{n}$ - number of individuals; $\mathrm{X}_{\mathrm{a}}$ - total average density of plants (individuals $/ \mathrm{m}^{2}$; $\mathrm{X}_{\text {pre }}-$ density of the pregenerative individuals (individuals $/ \mathrm{m}^{2}$ ); $\mathrm{X}_{\mathrm{g}}$ - density of generative individuals (individuals $/ \mathrm{m}^{2}$ ); $\mathrm{X}_{\text {post }}-$ density of postgenerative individuals (individuals $/ \mathrm{m}^{2}$ ); $\mathrm{I}_{\mathrm{r}}$ - recovery index; $\mathrm{I}_{\mathrm{a}}$ - aging index; $\mathrm{I}_{\text {rep }}$ - replacement index; $\Delta$ - age index; $\omega$ - efficiency index.

We found that $P$. chlorantha is distributed from $588 \mathrm{~m}$ a.s.1. to $1043 \mathrm{~m}$ a.s.l. Its locations mostly consisted of beech-hornbeam forests. In the plant communities with $P$. chlorantha, we found other orchid species. The species involved to the analysis were Platanthera chlorantha (Sp1), Ophrys sphegodes subsp. mammosa (Desf.) Soó ex E.Nelson (Sp2), Ophrys apifera Huds. (Sp3), Epipactis palustris (L.) Crantz (Sp4), Neottia nidus-avis (L.) Rich., (Sp5), Limodorum abortivum (L.) Sw. (Sp6), Neottia ovata (L.) Bluff \& Fingerh. (Sp7), Himanthoglossum formosum (Stev.) K.Koch (Sp8), Orchis purpurea Huds. (Sp9), Dactylorhiza romana subsp. georgica (Klinge) Soó ex Renz \& Taubenheim (Sp10). The eigenvalues for CCA axis 1 is $64.11 \%$, CCA axis $2-16.21 \%$ (Fig. 4).

Himanthoglossum formosum and Dactylorhiza romana subsp. georgica are separated from the main group of species in Fig. 4. Obviously, this is caused by their preferences to habitats with the lowest precipitation values and growing on slopes more gentle than other analysed orchids do.
In addition, these taxa prefer a bit more humidity than other species. One more taxon located considerably separately was Ophrys sphegodes subsp. mammosa. Obviously, this orchid is confined to the highest altitudes and lowest temperature in the Great Caucasus (Azerbaijan). The other seven species are almost not distinguishable according to the analysed environmental factors. Five of them, Platanthera chlorantha, Ophrys apifera, Orchis purpurea, Neottia nidus-avis, and Neottia ovata formed almost undivided group. At the same time, Limodorum abortivum demonstrated slightly more expressed preferences to higher altitudes, and lower values of temperature and air humidity, while Epipactis palustris showed a bit higher preferences to more moisturised habitats and steeper slopes.

\section{Morphometric analysis}

Table 4 presents results of the morphometric analysis. Comparison of the average morphological parameters of generative $P$. chlorantha individu- 
als showed that the generative shoots are the highest in Pop4, but they are the lowest in Pop5. The length and width of the generative shoots indicated the lowest values in Pop5. The highest values of leaf length and width were observed in Pop4. The highest number of flowers was registered in Pop4 and the lowest values of this parameter were in Pop5. The most number of veins was in Pop3, and the lowest values were in Pop2.

Cluster analysis showed that two main clusters revealed with a high bootstrap index $(100 \%)$. The first of them included Pop5. In this population, the morphological parameters of individuals were smaller than in other populations. The remaining populations with high bootstrap index (99\%) are divided into two subclusters. Four populations (Pop3, Pop4, Pop6 and Pop7) belonged to the second subcluster. They differed on the basis of the higher average morphological parameters of individuals than the other four populations
(Pop1, Pop2, Pop8, Pop9) belonging to the first subcluster. Populations of the first subcluster were located in the Guba and Gakh districts, while populations of the second subcluster originated from Qusar, Khizi, Shamakhi and Ismayilli districts (Fig. 5).

\section{Vitality structure}

In the investigated populations, we conducted a vitality analysis to study the viability of the $P$. chlorantha individuals. In all populations, a predominance of individuals of the upper and intermediate classes $(\mathrm{Q}>\mathrm{c})$ was found. They are classified as thriving. Iq values varied between 1.11 and 4.04, while IVC values ranged between 0.14 and 5.50. The highest values of Iq were observed in Pop2, while the lowest values in Pop7. High IVC values were observed in Pop7, while in other populations the IVC values were much lower (Table 5).

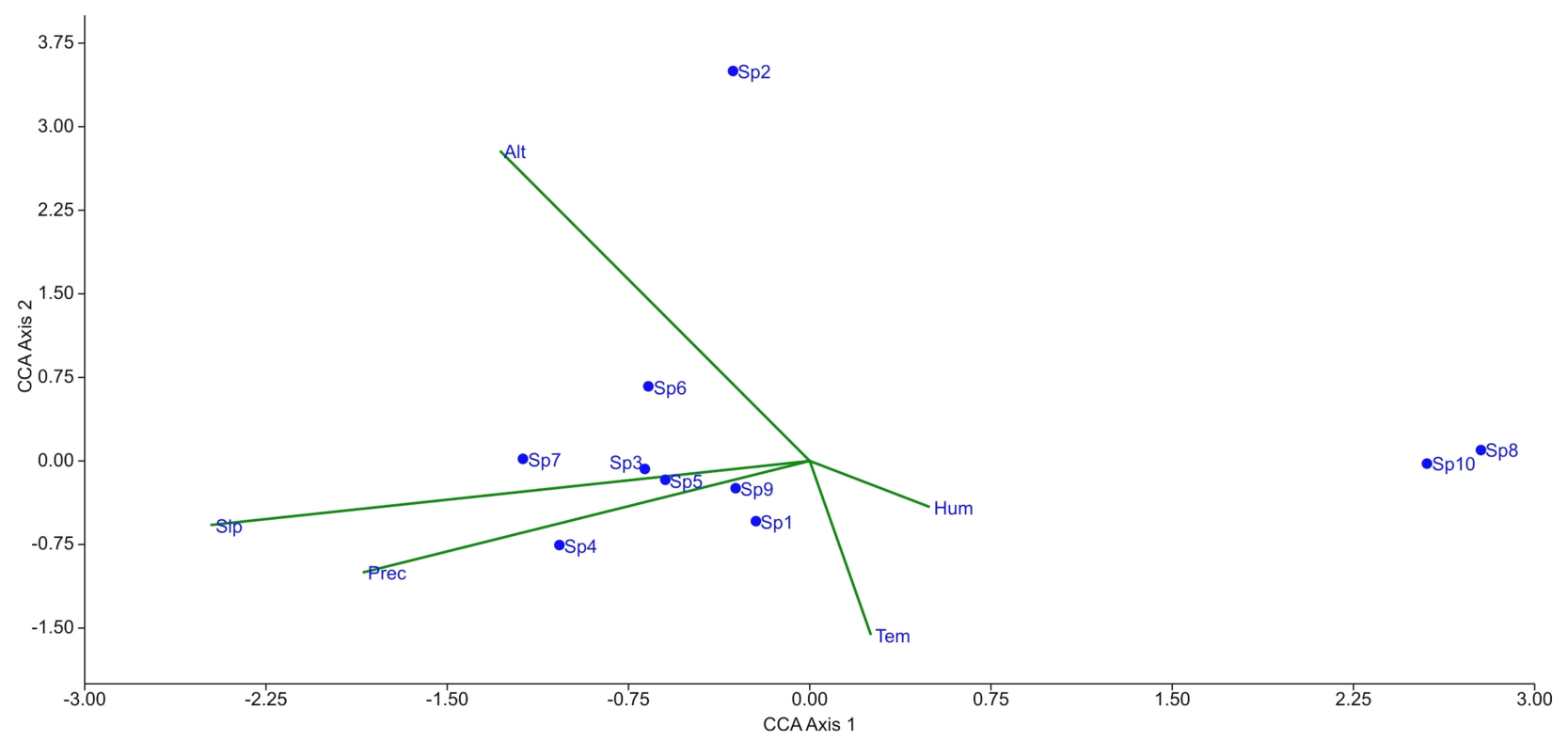

Fig. 4. Canonical correspondence analysis (CCA) ordination diagram of environmental preferences of orchid species in the Greater Caucasus on the basis of the mean environmental factor values. Environmental factors (Alt - altitude, Slp - slope exposure, Tem - temperature, Prec - precipitation, Hum - air humidity) are indicated by arrows of the biplot. Orchid species are indicated by blue dots. To reveal ecological gradients the mean environmental indicator values were plotted onto CCAordination diagram as supplementary environmental variables.

Table 4. Morphological parameters and their variability of generative Platanthera chlorantha individuals in the Greater Caucasus (Azerbaijan)

\begin{tabular}{|c|c|c|c|c|c|c|}
\hline Pop & $\begin{array}{c}\text { Length of generative } \\
\text { shoot }(\mathrm{cm})\end{array}$ & $\begin{array}{c}\text { Width of generative } \\
\text { shoot }(\mathrm{cm})\end{array}$ & Leaf length $(\mathrm{cm})$ & Leaf width $(\mathrm{cm})$ & $\begin{array}{c}\text { Number of } \\
\text { flowers }\end{array}$ & Number of veins \\
\hline 1 & $13.88 \pm 2.2$ & $0.23 \pm 0.1$ & $11.67 \pm 2.8$ & $5.47 \pm 1.3$ & $15.11 \pm 3.9$ & $13 \pm 2.4$ \\
\hline 2 & $14.89 \pm 3.1$ & $0.23 \pm 0.1$ & $12 \pm 2.6$ & $5.4 \pm 1.2$ & $15.22 \pm 4.7$ & $12.55 \pm 2.1$ \\
\hline 3 & $16.33 \pm 2.9$ & $0.34 \pm 0.1$ & $14.61 \pm 2.3$ & $5.17 \pm 1.4$ & $18.55 \pm 5.1$ & $18.78 \pm 4.5$ \\
\hline 4 & $19.44 \pm 5.4$ & $0.24 \pm 0.5$ & $16.44 \pm 5.6$ & $6.22 \pm 1.5$ & $21.11 \pm 7.1$ & $14.77 \pm 3.1$ \\
\hline 5 & $6.44 \pm 1.7$ & $0.22 \pm 0.1$ & $12.89 \pm 2.1$ & $4.19 \pm 0.7$ & $6.33 \pm 2.4$ & $14.11 \pm 3.5$ \\
\hline 6 & $16.32 \pm 4.2$ & $0.33 \pm 0.1$ & $14.45 \pm 1.9$ & $5.14 \pm 1.3$ & $18.16 \pm 4.5$ & $17.05 \pm 5.2$ \\
\hline 7 & $15.42 \pm 4.1$ & $0.34 \pm 0.1$ & $14.18 \pm 2.1$ & $5.2 \pm 1.2$ & $18 \pm 4.9$ & $16.37 \pm 4.8$ \\
\hline 8 & $15.22 \pm 3.2$ & $0.35 \pm 0.1$ & $13.55 \pm 2.4$ & $4.71 \pm 1.5$ & $16.44 \pm 4.9$ & $16.55 \pm 4.3$ \\
\hline 9 & $14.33 \pm 2.9$ & $0.35 \pm 0.1$ & $13.38 \pm 2.2$ & $5.38 \pm 1.2$ & $14.55 \pm 3.3$ & $15.11 \pm 3.8$ \\
\hline
\end{tabular}




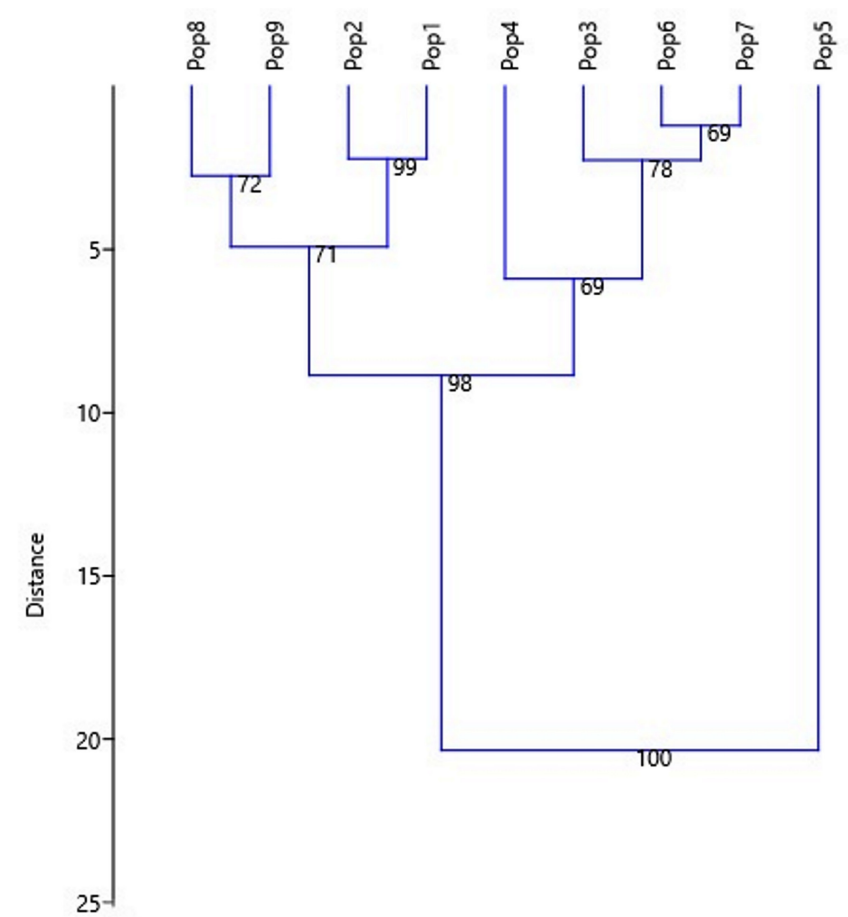

Fig. 5. The dendrogramm of the average values of morphological parameters of Platanthera chlorantha individuals in the studied populations.
During the study period, we observed that several biotic and abiotic factors influenced $P$. chlorantha individuals on the study sites. These factors include the temperature and precipitation, drought, erosion, floods, deforestation, grazing, habitat loss caused by land clearing and habitat fragmentation, removal of flowers or tubers, insect damage (Pop4, Pop5), decline in pollinator number, pollution (Pop5: pollution with oil), small number of individuals (Pop3, Pop4), urbanisation (Pop8), biological invasion (Pop7: rapid increase in number of invasive Robinia pseudacacia).

\section{Phenology of Platanthera chlorantha}

The phenology of $P$. chlorantha was studied in the Experimental Station. This was recorded using such stages as beginning of vegetation, appearance of generative shoots, beginning of flowering, mass flowering, withering of flowers, fruiting, seed shedding, and beginning rest time (Fig. 6).

Table 5. Characteristics of the vitality structure of Platanthera chlorantha populations in the Greater Caucasus (Azerbaijan)

\begin{tabular}{|c|c|c|c|c|c|c|c|}
\hline \multirow{2}{*}{ Pop } & \multicolumn{3}{|c|}{$\mathrm{A}$} & \multirow{2}{*}{ Q } & \multirow{2}{*}{ Iq } & \multirow{2}{*}{ IVC } & \multirow{2}{*}{$\mathrm{TP}$} \\
\hline & $\mathrm{a}$ & $\mathrm{b}$ & $\mathrm{c}$ & & & & \\
\hline 1 & 0.22 & 0.56 & 0.22 & 0.39 & 1.74 & 0.14 & thriving \\
\hline 2 & 0.22 & 0.67 & 0.11 & 0.44 & 4.04 & 0.20 & thriving \\
\hline 3 & 0.11 & 0.67 & 0.22 & 0.39 & 1.77 & 0.14 & thriving \\
\hline 4 & 0.26 & 0.48 & 0.26 & 0.37 & 1.42 & 0.14 & thriving \\
\hline 5 & 0.17 & 0.55 & 0.28 & 0.36 & 1.28 & 0.14 & thriving \\
\hline 6 & 0.32 & 0.42 & 0.26 & 0.37 & 1.42 & 0.14 & thriving \\
\hline 7 & 0.29 & 0.40 & 0.31 & 0.34 & 1.11 & 5.50 & thriving \\
\hline 8 & 0.22 & 0.52 & 0.26 & 0.37 & 1.42 & 0.14 & thriving \\
\hline 9 & 0.17 & 0.61 & 0.22 & 0.39 & 1.77 & 1.84 & thriving \\
\hline
\end{tabular}

Note: A - proportion of individuals in the vitality classes; Q - quality index; Iq - rank of thriving or depressive; IVC - index of vitality; TP - type of population.



\begin{tabular}{ll|l|l}
\hline & Rest time & Mass flowering \\
\hline & Beginning of vegetation & Withering of flowers \\
$\square$ & Appearance of generative shoots & Fruiting \\
$\square$ & Beginning of flowering & Seed shedding
\end{tabular}

Fig. 6. Phenology of Platanthera chlorantha in the Experimental Station of ANAS. 
The beginning of vegetation of $P$. chlorantha occurred in early November when the first leaf appeared. Generative shoots appeared in late February. The beginning of flowering and mass flowering occurred respectively in late April and from late May to late June. Fruiting and seed shedding started in early July and continued until late September.

In 2017, flowering was observed from 10 May to 27 May. In 2018, flowering began on 13 May. In 2019, flowering occurred from 17 May to 02 June. Thus, the average duration of flowering of one flower was 7-9 days in 2017, 13-15 days in 2018, and 8-10 days in 2019. The flowering duration of one individual was 17 days in 2017, 25-28 days in 2018, and 20 days in 2019.

\section{Discussion}

Until now, the age structure of $P$. chlorantha populations and morphological parameters of its individuals have been studied fragmentarily (Mursal \& Mehdiyeva, 2016). However, its ontogenesis has not been investigated yet. In this paper, the ontogenetic features of eight age classes of $P$. chlorantha were described for the first time in Azerbaijan. The analysis of the spatial and demographic structure of populations demonstrated that the status of the studied populations is ambiguous. For example, in Pop6 and Pop7, indices of density and number of individuals were higher than in other populations. Pop5 was characterised a good self-renewal process. The habitats of this population are highly susceptible to anthropogenic effects and oil pollution. We found the presence of young individuals indicating the processes of satisfactory self-maintenance. At the same time, the status of Pop1 causes some concern due to the predominance of generative and postgenerative individuals, as well as a high age index and weak recovery ability.

According to Landolt (1977) scale, $P$. chlorantha is a shade or semi-shade plant. Platanthera chlorantha prefers alkaline soils, grows on dry soils or on soils from medium dry to wet by avoiding very dry and very moist soils. On the scale of soil wealth with nutrients (especially nitrogen), it is ranked as a second type poor soil. The morphometric analysis showed that the individuals with the highest length of flower shoot are observed in Pop3, Pop4 and Pop6. The highest values of length and width of leaf, number of flowers are observed mainly in the Khizi Qizilgazma forest. This area is similar to Shamakhi-Ismayilli districts in terms of climate and edaphic features. Although the morphological parameters of individuals are satisfactory in these study sites, populations are at risk of extinction due to the small number of viable individuals. The lowest length of generative shoots and number of flowers were observed in Pop5. This population is the mostly affected site in terms of oil pollution and anthropogenic impact. The type of climate is characterised by dry and very hot summers, and mild winters. We assume that the hot and dry nature of the area, as well as additional impacts, led to the small size of individuals in the population. According to our results, the most favourable conditions for P. chlorantha are observed in Khizi, Qusar and Shamakhi districts where the climate is temperate, warm and humid, the soil belongs to the mountain-brownish type.

The vitality analysis showed that although the studied populations are located at different alttitudes and influenced by many biotic and abiotic factors, the structure of vitality is thriving in all populations.

\section{Conclusions}

The present investigation was dealt to the population status of the threatened species $P$. chlorantha in Azerbaijan. The conducted population-based studies of $P$. chlorantha in the Greater Caucasus in different habitats have been investigated. Our results indicated that $P$. chlorantha has a wide ecological variability. We found it from $588 \mathrm{~m}$ a.s.l. to $1043 \mathrm{~m}$ a.s.l. in various forest types. The most favourable conditions for P. chlorantha are the temperate, warm and humid climate and mountain brownish soils. Under such conditions, individuals have higher morphometric indices and a high viability. The studies in seven districts of Azerbaijan demonstrated that all populations were full-membered except for Pop3, Pop4, Pop5 and Pop8. Only Pop1 was classified as a transitional type, while the other populations were young. The highest morphological parameters were found for individuals in Pop3, Pop4 and Pop6. Apparently, this is associated with favourable soil and climatic conditions of these forests. This is indicated by the soil $\mathrm{pH}$, altitudes up to $1300 \mathrm{~m}$ a.s.l., where the climate is characterised as temperate, warm and humid. The climate and harsh environment determine the high number and high values of morphological parameters of $P$. chlorantha individuals. This is evidenced by the results of spatial and morphometric analyses. In all populations, the predominance of individuals of the upper and intermediate classes $(\mathrm{Q}>\mathrm{c})$ was noted. In this regard, they are classified as prosperous.

In order to better understand the environmental preferences of $P$. chlorantha, we suggest continuing monitoring and assessment of its population in the Greater Caucasus. The metadata allows us to assume that generalisation of jointly obtained demographic, ecological, phytocoenological data will be appropriate for a successful conservation and management of $P$. chlorantha. 


\section{Acknowledgements}

We kindly thank the anonymous reviewers and editors for their helpful comments which greatly improved the manuscript.

\section{References}

Alizade V.M., Mehdiyeva N.P., Karimov V.N., Ibrahimova A.G. 2019. Plants of the Greater Caucasus. Baku: Red N Line. 352 p.

Babaev M., Chafarova Ch., Hasanov V. 2006. Contemporary soil classification of Azerbaijan. Baku: Elm. 360 p. [In Azerbaijani]

Beideman I.N. 1960. The study of plant phenology. In: Field geobotany. Vol. 2. Moscow; Leningrad: AS USSR. P. 333-366. [In Russian]

Brook B.W., Sodhi N.S., Bradshaw C.J.A. 2008. Synergies among extinction drivers under global change. Trends in Ecology and Evolution 23(8): 453-460. DOI: $10.1016 /$ j.tree.2008.03.011

Ceballos G., Ehrlich P.R., Barnosky A.D., García A., Pringle R.M., Palmer T.M. 2015. Accelerated modern human-induced species losses: Entering the sixth mass extinction. Science Advances 1(5): e1400253. DOI: 10.1126/sciadv. 1400253

Cribb P.J., Kell S.P., Dixon K.W., Barrett R.L. 2003. Orchid conservation: a global perspective. In: S.P. Kell, K.W. Dixon, R.L. Barrett, P.J. Cribb (Eds.): Orchid conservation. Kota Kinabalu: Natural History Publications. P. 1-24.

Downey P.O., Richardson D.M. 2016. Alien plant invasions and native plant extinctions: a six-threshold framework. AoB Plants 8: plw047. DOI: 10.1093/ aobpla/plw047

Evans M.C., Watson J.E.M., Fuller R.A., Venter O., Bennett S.C., Marsack P.R., Possingham H.P. 2011. The spatial distribution of threats to species in Australia. BioScience 61(4): 281-289. DOI: 10.1525/bio.2011.61.4.8

Fay M.F. 2018. Orchid conservation: how can we meet the challenges in the twenty-first century? Botanical Studies 59(1): 1-16. DOI: 10.1186/s40529-018-0232-z

Hammer Ø., Harper D.A.T., Ryan P.D. 2001. PAST: Paleontological statistics software package for education and data analysis. Palaeontologia Electronica 4(1): 9.

Helm A., Hanski I., Pärtel M. 2006. Slow response of plant species richness to habitat loss and fragmentation. Ecology Letters 9(1): 72-77. DOI: 10.1111/j.14610248.2005.00841.x

Ipatov V.C., Kirikova L.A. 1998. Phytocenology. St. Petersburg. 314 p. [In Russian]

IPBES. 2019. Summary for policymakers of the global assessment report on biodiversity and ecosystem services of the Intergovernmental Science-Policy Platform on Biodiversity and Ecosystem Services. Bonn: IPBES secretariat. $56 \mathrm{p}$.

Ishbirdin A.R., Ishmuratova M.M., Zhirnova T.V. 2005. Life strategies of Cephalanthera rubra (L.) Rich. populations in the Bashkir State Nature Reserve. Vestnik of Lobachevsky University of Nizhni Novgorod 1: 85-98. [In Russian]
Ishkinina R.M., Ishmuratova M.M. 2007. Ontogenesis of the lesser butterfly-orchid (Platanthera bifolia (L.) L.C. Rich.). In: Ontogenetic Atlas of Plants. Vol. 5. YoshkarOla: Mari State University. P. 283-285. [In Russian]

Johnson C.N, Balmford A., Brook B.W., Buettel J.C., Galetti M., Guangchun L., Wilmshurst J.M. 2017. Biodiversity losses and conservation responses in the Anthropocene. Science 356(6335): 270-275. DOI: 10.1126/science.aam9317

Landolt E. 1977. Ökologische Zeigerwerte zur Schweizer Flora. In: Veröffentlichungen des Geobotanischen Instituts der ETH, Stiftung Rübel in Zürich. Vol. 64. $208 \mathrm{p}$.

Le Roux J.J., Hui C., Castillo M.L., Iriondo J.M., Keet J.H., Khapugin A.A., Médail F., Rejmánek M., Theron G., Yannelli F.A., Hirsch H. 2019. Recent Anthropogenic Plant Extinctions Differ in Biodiversity Hotspots and Coldspots. Current Biology 29(17). P. 2912-2918.e2. DOI: 10.1016/j.cub.2019.07.063

Li J., Gale S.W., Kumar P., Zhang J., Fischer G. 2018. Prioritizing the orchids of a biodiversity hotspot for conservation based on phylogenetic history and extinction risk. Botanical Journal of the Linnean Society 186(4): 473-497. DOI: 10.1093/botlinnean/box084

Mamedov G.Sh., Khalilov M.Y., Mamedova S.Z. 2010. Ecological Atlas. Baku: Cartographic Factory. 176 p. [In Azerbaijani]

Mirkin B.M., Naumova L.G., Solomeshch A.I. 2001. Modern vegetation science. Moscow: Logos. 264 p. [In Russian]

Mursal N., Mehdiyeva N.P. 2016. Ontogenetic structure and phytocenotic characteristic of coenopopulations of rare species Platanthera chlorantha (Cust.) Reichenb. in Guba district of Azerbaijan. Proceedings of Biological and Medicinal Sciences 71(3): 39-44.

Pimm S.L., Raven P. 2000. Biodiversity: extinction by numbers. Nature 403: 843-845. DOI: 10.1038/35002708

Primack R.B. 1985. Patterns of flowering phenology in communities, populations, individuals and single flowers. In: J. White (Ed.): The Population Structure of Vegetation. Dordrecht: Springer. P. 571-593. DOI: 10.1007/978-94-009-5500-4 24

Red Data Book of the Republic of Azerbaijan (rare and endangered species of plants and fungi). Baku, 2013. 665 p. [In Azerbaijani]

Rzazade R.Y. 1952. Genus of Platanthera L.C. Rich. In: D.I. Sosnovski, I.I. Karyaqin (Eds.): Flora of Azerbaijan. Vol. 2. Baku: AN Azerbaijan SSR. P. 259260. [In Russian]

Seaton P., Kendon J.P., Pritchard H.W., Puspitaningtyas D.M., Marks T.R. 2013. Orchid conservation: The next ten years. Lankesteriana 13(1-2): 93-101. DOI: 10.15517/lank.v0i0.11545

ter Braak C.J.F. 1986. Canonical correspondence analysis: a new eigenvector technique for multivariate direct gradient analysis. Ecology 67(5): 1167-1179. DOI: 10.2307/1938672

Uranov A.A. 1975. Age spectrum of phytopopulation as a function of the time of energy wave processes. Biological Sciences 2: 7-34. [In Russian] 
Vakhrameeva M.G., Tatarenko I.V., Varlygina T.I., Torosyan G.K., Zagulskii M.N. 2008. Orchids of Russia and adjacent countries (within the borders of former USSR). Ruggell: A.R.G. Gantner. 690 p.

Wraith J., Pickering C. 2019. A continental scale analysis of threats to orchids. Biological Conservation 234: 7-17. DOI: 10.1016/j.biocon.2019.03.015

Zaugolnova L.B., Zhukova L.A., Komarov A.S., Smirnov O.V. 1988. Coenopopulation of plants (essays of population biology). Moscow: Nauka. 184 p. [In Russian]
Zhivotovsky L.A. 2001. Ontogenetic States, Effective Density, and Classification of Plant Populations. Russian Journal of Ecology 32(1): 1-5. [In Russian]

Zhukova L.A. 1995. Population life of meadow plants. YoshkarOla. 224 p. [In Russian]

Zlobin Y.A. 1989. Theory and practice of assessment of vital content of plant populations. Botanicheskii Zhurnal 74(6): 769-781. [In Russian]

Zlobin Y.A., Sklyar V.G., Klimenko A.A. 2013. Populations of rare plant species: theoretical bases and methods of study. Sumy: Universitetskaya kniga. 439 p. [In Russian]

\title{
СОСТОЯНИЕ ПОПУЛЯЦИЙ И ЭКОЛОГИЯ PLATANTHERA CHLORANTHA (ORCHIDАCЕАЕ) НА БОЛЬШОМ КАВКАЗЕ (АЗЕРБАЙДЖАН)
}

\author{
Н. Мурсал, Н. П. Мехтиева, А. Г. Ибрагимова \\ Институт ботаники Наџиональной Академии Наук Азербайджана, Азербайджан \\ e-mail: nigarbiology1292@mail.ru
}

\begin{abstract}
Схема долговременной охраны природы обычно касается угрожаемых и наиболее редких видов. Изучение видов, занесенных в Красную книгу, необходимо для определения их категории угрожаемости и оптимальных мер их охраны. Orchidaceae является самым привлекательным семейством среди всех растений в мировой флоре. Из-за декоративных, лечебных, пищевых особенностей видов орхидей их численность сокращается. В Красную книгу Республики Азербайджан включено 17 угрожаемых видов орхидей. Одна из них - Platanthera chlorantha. Ранее онтогенетическая и морфометрическая структура популяций P. chlorantha изучалась лишь отрывочно. Тем не менее, виталитетная структура ее популяций и влияние на них окружающей среды в Азербайджане ранее не изучались. Целью настоящей статьи было исследование онтогенетической, демографической и виталитетной структуры популяций $P$. chlorantha для освещения влияния климатических и эдафических факторов на морфометрическую вариабельность особей. Полевые исследования были проведены в 2016-2019 гг в Хызинском, Сиазаньском, Губинском, Гусарском, Шемахинском, Исмаиллинском и Гахском районах Большого Кавказа с использованием популяционных и геоботанических методов. Морфометрические исследования были проведены на 30 случайным образом выбранных генеративных особях в девяти исследованных популяциях. Взаимосвязи между распространением орхидей и их экологическими предпочтениями были проанализированы с использованием методов канонического корреспондентного анализа. Также была изучена фенология P. chlorantha. Мы обнаружили, что умеренный, теплый, влажный климат и горный коричневатый тип почв являются наиболее благоприятными для произрастания P. chlorantha.
\end{abstract}

Ключевые слова: видовое обилие, виталитетная структура, исчезающий вид, морфологическая изменчивость, онтогенетическая структура, ординация, орхидея, фенология 